ALMEIDA, José M. F. Virtual Informatics Museum. In: PUTNIK, Goran D; CUNHA, Maria Manuela (Eds). Encyclopedia of Networked and Virtual Organizations. Information Science Reference, Hershey PA, USA, 2008. ISBN 159904885X.

\title{
Virtual Informatics Museum
}

\section{José Almeida}

falmeida@dsi.uminho.pt

\section{Introduction}

The only Virtual Informatics Museum - VIM - existing in Portugal was conceived over personal memoirs and a long investigation and research work.

The first publication by VIM was done over the first trimester of 1997 in Terravista, a site created by the Ministry of Science and Technology (Ministério da Ciência e Tecnologia - MCT). On its first version, available in Terravista Project, the contents were not chronologically ordered. This option motivated some criticism by users demanding this chronological order which led to a subdivision in two sections of the VIM contents:

- Pre history to Informatics: starting chronologically with Foz Coa pictures (18.000 B.C.) and ending with the description and photographs of ABC (Atanasoff-Berry Computer) built in Iowa University, USA, by John Vincent Atanasoff and Clifford Berry between 1939 and 1942.

- Virtual Informatics (Computer Science) Museum: beginning with ENIAC public presentation, February $1^{\text {st }} 1946$ and ending with description and photos of SE/30 Macintosh Computer made available by Apple Computers in 1989.

Both sections offered substantial resources in the shape of text, digital photos and links appealing to recurrent visits, investigations and researches.

The site Terravista, created by the MCT, was sold and is now a private company denominated TERRAVISTA, SA.

Those public memoirs of VIM were lost although it may be possible to reconstruct them from backup copies.

The VIM had as main purpose to help Management and Economics students of Évora University, teaching them how to use a data communication net and sites to search for documentation and texts beyond Libraries and Manuals.

The entrance "gate" to VIM had to be electronic and both a computer and an "account" in the data communication net would serve as a ticket and mean of transport. The student should obtain an account in an ISP - Internet Service Provider - and connect his/her computer to the net. 
In Portugal, in 1997, the main ISP was Portugal Telecom which sold Netpac, a box containing an installation manual and three diskettes of 3"1/2 one of which had the 2.0 version of Netscape Browser.

The student should also have a modem (provided by Portugal Telecom) and a fixed phone contract. This system was costly once the user had to pay in a monthly basis the contract of the fixed phone and the use of the line (reduced to a local call cost in some places). Furthermore the speed of data transmission was very slow - about 9600 bps and if one used the phone line for conversation the data communications would be unavailable and vice-versa.

In order to overcome these restrictions, on the $4^{\text {th }}$ of July 1997 , the VIM became hosted by a server of Évora University and it became available via RCCN - Rede da Comunicação Científica Nacional (National Scientific Communication Net) which was the most recent communication net of the Portuguese Universities until then and could reach a transmission speed of 96 Kbps.

Students and Professors of Évora University could access VIM through the University LAN- Local Area Network - and its use within the campus was free of costs.

Obviously, the external access (from a geographical place other than the campus) to VIM had to be done through Telepac or another ISP. However within different Universities the access was made via RCCN.

On the $7^{\text {th }}$ July 1997, the national newspaper Expresso reported in its XXI section the VIM and also in July 1997 there were already links to VIM in Altavista Browser, in the University of Manchester (UK) site, in the University of Glasgow (UK) site and in the Portuguese browser "aeiou".

In the beginning of 1998 it started to be used a free statistical system provided by Webalyser to compute de use of VIM. In the end of 1998 the average of monthly accesses to VIM in the University of Évora was 143 and the average of monthly accesses to "Pre history" was 114.

$53 \%$ of the total accesses were from Portugal, 24\% were from unknown origins, $7 \%$ from commercial places in the USA and 7\% were from Brazil.

Since October 1998, Webalyser System began to be used also in the VIM site in the server of Minho University.

As the conceiver and designer of VIM moved to the Information System Department (ISD) of the University of Minho, the execution of the project VIM was also transferred from the server of Évora University to the server in University of Minho. 
The purpose of VIM expanded to the students licensing in Information Management and Engineering in the University of Minho, teaching them how to use a data communication net and sites to search for documentation and texts beyond Libraries and Manuals, as well as support the development of capacities of Multimedia students and graduates who were taking Masters in Information Systems at the same University. As a result the VIM design was changed now including graphical animation of some pictures, new themes like the $1^{\text {st }}$ Informatics National Meeting (Leiria, 1997), the $1^{\text {st }}$ Portuguese Congress in Informatics (Lisbon, 1980), new links, the possibility of on-line reading of PDF - Portable Document Format - books, the possibility of watching online videos using a "streaming" system as well as several exhibitions inside and outside campus namely in Polytechnic Institutes, Professional Schools, High Schools, Government Organizations and Civil Associations.

In the beginning of 2003 it was applied to the VIM site of Minho University another statistical and counting system providing more accurate data than Webalyser.

This new system - Nedstatbasic, recently nominated Webstats4U - provides data concluding that the VIM internationalized mostly through Portuguese and Spanish Idiom accesses.

From November 1998 until now, the quantitative of accesses to VIM totalized 145684 with a monthly average of 1694 and a monthly average growth of 5\%.

$51,8 \%$ of the accesses are from South America, 43,5\% are from Europe and 1,4\% are from North America..

$50 \%$ are from Brazil, 41,7\% are from Portugal, 1,3\% from Uruguai, 1,3\% from USA, $0,5 \%$ from Spain and 0,5\% from Mexico.

91,5\% have origin in countries where Portuguese or Spanish are spoken, 1,6\% were English in spoken and 0,3\% where French is spoken.

\section{Background}

After the official commemoration of the 50 years of the public presentation (Goldstine, 1993) of ENIAC - Electronic Numeral Integrator and Computer, one of the first electronic computers build by Men, whose public presentation took place at Penn's University Houston Hall on February $1^{\text {st }} 1946$ - there was a boom in records referring to the construction and manipulation of those subsystems all over the world. These records have been obtained mainly through Virtual Museums built over electronic repositories accessed via Internet. As examples we may find the VLmp - Virtual Library museum page (Bowen, 1995) - created in 1994 by Jonathan Bowen at Oxford University and 
later moved to the Museophile site by ICOM - International Council of Museum; the reconstruction of computers (Napper, 1998), (Sale, 1993), and (University of Cambridge, 1999), magazine articles as "Qui a invente l'ordinateur" (Les Chaier de Science et Vie, 1996), books like "Roteiro Prático da Internet" (Magalhães, 1995), "A History of Manchester Computers" (Lavington, 1998), "A Computer called Leo" (FERRY, 2003), Recommendations of International Entities as IFIP - International Federation for Information Processing - (IFIP TC3 / TC9, 1998), the integration of physical memoirs in already existing Museums such as "The Museum of Science \& Industry in Manchester" where we can find a replica of Baby Machine (The Museum of Science \& Industry in Manchester, 1998) and projects for Museums devoted to this theme.

Countries with a museological tradition, as the United Kingdom or France, integrate the memories of computational subsystems in already existing museums.

Some European Universities or connected Institutions seek for building memories' repositories containing subsystems from several origins. Most repositories belong to Virtual Museum gender.

However, in some countries there are real Computer Museums divulged by virtual sites. In Sweden it is known a real Museum build in Stenungsund, north from Goteborg. This museum is simultaneously an "Internet Cafe" and its memory integrates over 250 personal computers initially used in an exhibition (Hogia, 1993).

Germany centred its real Museum at Heinz Nixford Forum (Heinz Nixdorf, 1996) considered the greatest computer museum of the world.

In the USA The Museum of Computer in Boston joined the Museum of Science (Museum of Science, 1999) in just one site.

In Portugal there is no real Museum constituting a memoir repository of computational subsystems.

The so called Museu Nacional da Ciência e da Técnica (Museu Nacional da Ciência e da Técnica , 2005), raised at the end of the 60's, beginning of the 70's, by the late professor Mário Silva of the Physics Department of the Faculty of Sciences of Coimbra University, is in the Palacete Sacadura Botte (Museu Nacional da Ciência e da Técnica, 2005) in the Rua dos Coutinhos in Coimbra and has place for exhibitions in Colégio das Artes.

Some of the material part of this patrimony can be found at the exhibition in Associação Industrial do Minho - at Braga (Associação Industrial do Minho, 2005). 


\section{Main Focus of Article}

Opposite from USA and the United Kingdom, the first entities to use electronic computers in Portugal were not Universities.

The first electronic computers with execution of the resident program were used in Portugal by L.N.E.C. (Laboratório Nacional de Engenharia Civil) - National Laboratory of Civil Engineering - Stantec Zebra, 1959 (Morais ... [et al.], 1987) - and by Hidro Eléctrica do Cávado - IBM 650, on the first months of 1960 (IBM, 1987),

Only at the end of the 60's, beginning of the 70's computers started to be used in the Portuguese Universities existing at the time. Until then some Portuguese Universities recurred to those services in Centro de Cálculo da Fundação Calouste Gulbenkian, by the Centro de Cálculo of L.N.E.C. and by the Data Processing Centres of some Portuguese companies (Morais ... [et al.], 1987).

The first computer courses - post graduation - began to be lectured in Portugal in the Universidade Nova de Lisboa only in (FCT UNL, 1975).

Portugal was never a computer constructor country nor lodged any constructor's complete production line.

The only computer totally conceived and built in Portugal was the ENER 1000. Conceived in the Physics Department of the Coimbra University, was publicly presented at the Portugal "Workshop on Signal Processing and Its Applications" in Póvoa do Varzim, in September/October 1982 (CEREBRO, 1983). Its commercialization was a total failure.

In the 70's, a commercial policy of equipment substitution by the main computer sellers in Portugal - IBM, NCR and UNIVAC - provoked the destruction of several subsystems.

The collective memory of Portuguese society regarding Information and Communication Technologies is very recent, fundamentally built over information published by the Media.

The memory of the graduates of Portuguese Universities concerning Information and Communication Technologies goes back to the 80's when there was a boom of the Personal Computers use.

The Portuguese lot of Information and Communication Technologies remains in some still existing companies, some Institutions and mostly on the memories of the ones that built, installed, handled and promoted the evolution of those subsystems.. What is not yet lost is at risk of oblivion due to natural causes. 
The Portuguese memories of the Information and Communication Technologies are not, naturally, part of the Universities. Nevertheless Universities are, obviously the adequate place for its reconstitution.

The VIM constitutes a Net Virtual Organization which is a repository of Portuguese Information and Communication Technologies memories under the theme of the "Encyclopaedia of Networked and Virtual Organizations" and is already fit in by (ICOM, 2006) - International Council of Museums - and by the MUSEUMS OF THE WORLD (MUSEUMS OF THE WORLD, 2006).

\section{Present implementation}

The present implementation is not stable. VIM is a living Net Virtual Organization always under improvement.

The content of the museum is built mainly with digitalized texts, digitalized photos, digitalized videos and some applets. Those objects and its backup occupies $240 \mathrm{MB}$ on magnetic discs of a server at the Information Systems Department of Minho University - Portugal.

Pages are written in standard html - Hyper Text Markup Language -, so people are free to use any browser under any OS - Operating System - to reach VIM.

Present statistics concerning VIM shows the use of:

\begin{tabular}{|c|c|}
\hline Browsers & $\%$ \\
\hline Internet Explorer 6.x & $80.3 \%$ \\
\hline Mozilla FireFox 2.x & $10.6 \%$ \\
\hline Mozilla FireFox 1.x & $3.0 \%$ \\
\hline Safari 1.x & $3.0 \%$ \\
\hline Opera 9.x & $1.5 \%$ \\
\hline Unknown & $1.5 \%$ \\
\hline OS & $77.3 \%$ \\
\hline Windows XP & $10.6 \%$ \\
\hline Windows 98 & $9.1 \%$ \\
\hline Mac OS & $1.5 \%$ \\
\hline Windows 2000 & $1.5 \%$ \\
\hline Unknown &
\end{tabular}

Main page provides the user with an introductory text explaining what is VIM, what is its content and what is its purpose.

The user can chose from several anchor where he wants to go.

From the upper right corner the user can choose a directory of contacts, frequent asked questions, site map and links to related URL's all over the world. 
On central banner user can choose to navigate by theme or to navigate in a chronologic fashion. Namely choosing "Referências" user will access to news and comments about VIM.

From the left lower corner the user can reach the last object added to VIM.

Future technology will be used on VIM as released and tested as good sustaining the principle of universal access provided to users.

Moreover for last eight years the cooperation of VIM had been required, on lectures, on public contests, on public conferences and to build temporary exhibitions.

In temporary exhibitions most of the objects showed are the original that had been photographed and are part of the content of VIM.

Some of the temporary exhibitions had been built integrated with others namely on telecommunications exhibitions - "Do bit ao Terabyte", (From bit to Terabyte, 2006) on libraries "b-in espaço", space b-in - and press exhibitions - "Do códice à palavra impressa", (from Codice to printed word, 2006).

Geographic distribution of temporary exhibitions spread from North of Portugal Felgueiras, Guimarães, Braga, Santo Tirso - to Lisbon.

The quantity of built temporary exhibitions had reach fourteen till 2006 NOV 24.

At least two projects has been launched with inspiration and cooperation of VIM:

MEMTSI - Memories of Technologies and Information Systems, 2005 (MEMTSI, 2006);

MEMTIC - Memories of Information and Telecommunication Technologies, 2006 (MEMTIC, 2006).

On public conferences some members, namely archaeologists and sociologists has expressed they intend to launch Virtual Museums supported on their projects.

VIM has reciprocal links to other virtual communities namely in UK, USA and South America - Brasil.

Nevertheless ICOM - International Council of Museums - includes VMLP - Virtual Museums Library Pages that is the "repositorium" of this virtual community.

Some colleagues started preliminary studies to apply some new technologies to VIM like 3D images, holograms, VRML and to launch new releases of VIM to fit on PDA and on mobile phones.

\section{Future Trends}

The emergent tendencies in the development and use of Net Virtual Organization, namely under the scope of Informatics (Computer Science) History, are its extension as 
a teaching support "Courses in the History of Computing" (Courses in the History of Computing, 2006). Most emails received at the address of VIM come from students and teachers from high schools, professional schools and Universities where Portuguese is spoken.

The growth of VIM visitors registered by Webstats4U since 2003 is very significant (Webstats4U, 2006).

The historic registry of statistic data referring to VIM is registered in an excel sheet since November 1998 to the present date.

By example, for the last five years:

\section{Procurement}

Unit: hits per month

\begin{tabular}{|l|r|r|r|r|r|}
\hline & 2002 & 2003 & 2004 & 2005 & 2006 \\
\hline Mês & Quant. & Quant. & Quant. & Quant. & Quant. \\
\hline & & & & & \\
\hline Jan & 1008 & 1506 & 1724 & 2526 & 5608 \\
\hline Fev & 1488 & 1776 & 1535 & 2825 & 5827 \\
\hline Mar & 2324 & 2102 & 3280 & 4224 & 7674 \\
\hline Abr & 1843 & 1860 & 2097 & 3990 & 5987 \\
\hline Mai & 1771 & 2427 & 2064 & 3641 & 5465 \\
\hline Jun & 1481 & 2020 & 1814 & 3147 & 5342 \\
\hline Jul & 1155 & 1540 & 1927 & 2121 & 4434 \\
\hline Ago & 1825 & 1510 & 2636 & 2896 & 4980 \\
\hline Set & 2318 & 1734 & 3261 & 3940 & 4940 \\
\hline Out & 2291 & 2186 & 4018 & 4897 & 6069 \\
\hline Nov & 2094 & 2145 & 3377 & 4945 & 3136 \\
\hline Dez & 1397 & 1201 & 2574 & 3180 & \\
\hline & & & & & \\
\hline Total & $\mathbf{2 0 9 9 5}$ & $\mathbf{2 2 0 0 7}$ & $\mathbf{3 0 3 0 7}$ & $\mathbf{4 2 3 3 2}$ & $\mathbf{5 9 4 6 2}$ \\
\hline
\end{tabular}

Emergent has been also the use of memorized data to support contents of other works:

Engenho e Obra - Engenharia em Portugal no Séc XX (Engenho e Obra 2000, 2000)

Multimedia Technology and 3D environments used in the preservations and dissemination of Portuguese cultural heritage ( Marcos ... [et all], 2002)

“Assertions: A Personal Perspective" author Tony Hoare April-June 2003 issue of IEEE Annals of History of Computing (Hoare, 2003)

Memórias das Tecnologias e dos Sistemas de Informação em Portugal (Beira [et al.], 2004),

Protagonistas das Tecnologias e dos sistemas de informação em Portugal (Beira [et al.], 2004), 
Analysing the statistics existing since November 1998 and some more recent whose collection started in 2003 it is shown a continued growth of the VIM use as well as its expansion in countries where Portuguese and Spanish are spoken and it may be considered that future tendencies are of growth in the use and diversification in the use of the VIM.

The Information and Communication Technologies evolution will have impact on the VIM as long as it contributes to its objective. Therefore will exist opportunities to research development on that subject.

Moreover the number of existing objects not yet registered in the VIM will raise the opportunity to develop projects in the Computing History area, namely in Portugal.

\section{Conclusion}

The increase in support capacity for data memory, the decrease of its physical dimension, the increase in computer processing speed, the easy connection of devices of fixed and moving images, sound and text made possible the creation of virtual Organizations which represent reality as a whole or in part.

The use of software that allows to manipulate data memorized in the virtual Organizations and to present it to the user in a 3 dimensional fixed or moving format makes the access to those Organizations easier and more pleasant.

The expansion of the communications net and the increase of speed in which objects move in their support between sender and receiver made possible the diffusion of virtual Organizations available in Net.

The VIM is a Virtual Organization in Net which has been developed, divulged and used in a broad spectre in Planet Earth; 51,2\% of the accesses come from South America, 44,2\% from Europe, 1,4\% from North America, 0,5\% from Central America, 0,3\% from Asia, $0,0 \%$ from Australia and 1,7\% from other places (Webstats4U , 2006)

The Virtual Organizations in Net, and VIM in particular, generate opportunities for the development of investigation applied to this area and allow people enjoy in a friendly way the reality anywhere in the Planet where exists an access to a data communication net.

\section{References}


Associação Industrial do Minho (Minho's Industrial Association) - in Braga (2005) $\begin{array}{llll}\text { Retrieved } & 2006 & \text { NOV } & \text { 20, }\end{array}$ http://www.dsi.uminho.pt/museuv/exibit/expoaim/expoaim.html

Beira, Eduardo ... [et al.] (2004) "Protagonistas das Tecnologias de Informação em Portugal” - Associação Industrial, Minho Braga 2004 ISBN 972-99502-4-5 237p.

Beira, Eduardo ... [et al.] (2004), "Memórias das tecnologias e dos sistemas de informação em Portugal” - Ass. Ind. Minho Braga 1ª ed. 2004 ISBN 972-99502-3-7 $322 \mathrm{p}$.

Bowen, Jonathan (1995) Retrieved 2006 -11- 20, from http://vmoc.museophile.org/

CEREBRO, (1983) CEREBRO - REVISTA DE INFORMÁTICA e GESTÂO - 15 FEV./15 MAR. Lisboa 1983: "EDITORIAL"

Courses in the History of Computing (2006) Retrieved 2006 NOV 20, from http://www.dcs.warwick.ac.uk/ mck/HoC Courses.html

Engenho e Obra 2000 (2000) Retrieved 2006 NOV 20, from http://esxx.innovagency.com/esxx publicacao 01.asp?publicacao=1

FCT UNL Departamento de Informática (1975) Retrieved 2006 NOV 20, from http://www.di.fct.unl.pt/cap.html

FERRY, Georgina (2003), “A computer called LEO” - Harper London, 2003 ISBN 184115-186-6

From bit to Terabyte, (2006) Retrieved 2006 NOV 25, from http://www.expohistoriacomputador.org/cpu/default.php

from Codice to printed word, (2006), Retrieved 2006 NOV 25, from http://www.fpc.pt/FPCWeb/museu/displayconteudo.do2?numero=20026

Goldstine, Herman H. (1993). "The Computer from Pascal to von Neumann" , Princeton University Press, USA 1993 ISBN 0-691-02367-0 (paperback), pages 227 and following.

Heinz Nixdorf Fórum (1996) - Retrieved 2006 NOV 20, from http://www.hnf.de/museum/index en.html

Hoare, Tony (2003) April-June 2003 issue of IEEE Annals of History of Computing "assertions: A Personal Perspective" Retrieved 2006 NOV 20, from http://csdl2.computer.org/persagen/DLAbsToc.jsp?resourcePath=/dl $/ \mathrm{mags} / \mathrm{an} / \&$ toc $=\mathrm{com}$ $\mathrm{p} / \mathrm{mags} / \mathrm{an} / 2003 / 02 / \mathrm{a} 2$ toc.xml

Hogia Pcmuseum (1993) - Retrieved 2006 NOV 20, from http://www.hogia.se/pcmuseum/index.html 
IBM, (1987) “IBM 50 anos em Portugal", Department of Communications and External Programs of Portuguese IBM S.A. Lisboa 1987, p. referencing 1959

ICOM (2006) - Retrieved 2006 - 11 - 20, from http://icom.museum/vlmp/computing.html

IFIP, TC3 / TC9 (1998) Join Task Group, "History in Computer Curriculum" - 1998 October, prepublication copy - Retrieved 2006 NOV 20, from http://portal.acm.org/citation.cfm?id=297753

Lavington, Simon (1998), "History of Manchester Computers" - The British Computer Society, Manchester UK 1998 ISBN 1-902505-01-8

Les Chaier de Science et Vie, (1996) Chaier de Science et Vie no 36 Science \& Vie Paris 1996, “Qui a invente l'ordinateur”-ISSN 1157-4887

Magalhães, José (1995), "Roteiro Prático da Internet" - Quetzal Editores Lisboa 3 ${ }^{a}$ edição 1995 ISBN 972-564-226-0

Marcos, Adérito Fernandes Bernardes, P. Sá, Vítor J. (2002) "MULTIMEDIA TECHNOLOGY AND 3D ENVIRONMENTS USED IN THE PRESERVATIONAND DISSEMINATION OF PORTUGUESE CULTURAL HERITAGE'(2002) - Consejeria de Education, Ciencia e Tecnologia NOV 2002 ISBN 84- 95251-79-5 vol3. págs. 1335 a 1339

MEMTSI, (2006), Retrieved 2006 NOV 25 from http://www3.dsi.uminho.pt/memtsi/ MEMTIC, (2006). Retrieved 2006 NOV 25 from http://www3.dsi.uminho.pt/memtsi/sitic_06.htm Morais, Carlos Campos [et al.] (1987). "40 anos de Computação Científica e Técnica no L.N.E.C.” - Lisboa, ,L.N.E.C., 1987 Anexo II p. 91 to 97

Morais, Carlos Campos ... [et al.] (1987). “40 anos de Computação Científica e Técnica no L.N.E.C.” - Lisboa, L.N.E.C., 1987 p. 4 and p.33

Museu Nacional da Ciência e da Técnica (2005) - Retrieved 2006 NOV 22, from http://www.mnct.mctes.pt/

Museum of Science (1999) - Retrieved 2006 NOV 20, from http://www.mos.org/tcm/tcm.html

MUSEUMS OF THE WORLD (2006)- the global museum project Koenigsallee 106, 40215 Duesseldorf, Germany. Retrieved 2006 NOV 20, from http://www.museum.com/jb/museum?id=37862

Napper, Brian (1998) Retrieved 2006 NOV 20, from http://www.computer50.org/index.html

Sale,Tony (1993) Retrieved 2006 -11- 20, from http://www.codesandciphers.org.uk/ 
The Museum of Science \& Industry in Manchester (1998) - Retrieved 2006 NOV 21, from http://www.msim.org.uk/Galleries.asp?menuid=1027

University of Cambridge, Computer Laboratory (1999) Retrieved 2006 NOV 20, from http://www.cl.cam.ac.uk/UoCCL/misc/EDSAC99/

Webstats4U - 2 (2006) Retrieved 2006- 11 - 20, from http://www.webstats4u.com select contadores e estatísticas and follow link My Statistics -> Where do visitors come from Webstats4U (2006) - Retrieved 2006 NOV 20, from http://www.dsi.uminho.pt/museuv/ select contadores e estatísticas and follow link My Statistics $->$ Compare traffic by month

\section{Key Terms and Their Definitions}

History - Description of a series of events that took place in a time/place referential.

Informatics - Science of rational treatment of information by automatic means, considered a support of knowledge and communications in the technical, economical and social areas.

Informatics Virtual Museum - As the gate to the virtual museum is electronic, a computer and an Internet account serve as your entrance ticket and transportation. For the Informatics Virtual Museum (Museu Virtual de Informática) the Internet site is http://www.dsi.uminho.pt/museuv/ which means it is placed in Portugal, at the Information Systems Department of Minho University.

Memory - Persona ability to remember facts, events and things.

Systems - Set of parts that together contribute to a purpose.

Museum - Place where objects are stored and exhibited to the public.

Net - System of connections where you can navigate, namely in seek of information.

Virtual - Images of real places and objects.

Virtual Museum - Organized collection of electronic artefacts and information resources - virtually anything that can be digitized. This collection may include paintings, drawings, photographs, diagrams, graphs, recordings, video segments, newspaper articles and transcripts of interviews, numerical databases and can also host other items which can be saved on its file server. It may also offer references to relevant resources for the museum around the world.

Virtual Organization in Net - Image of a real entity which has net structure that can be accessed through a data communication net. 
